\title{
Glycosylation: Rising Potential for Prostate Cancer Evaluation
}

\author{
Anna Kałuża *(D), Justyna Szczykutowicz (D) and Mirosława Ferens-Sieczkowska (D) \\ Department of Chemistry and Immunochemistry, Wroclaw Medical University, Sklodowskiej-Curie 48/50, \\ 50-369 Wroclaw, Poland; justyna.szczykutowicz@umed.wroc.pl (J.S.); \\ miroslawa.ferens-sieczkowska@umed.wroc.pl (M.F.-S.) \\ * Correspondence: anna.kaluza@umed.wroc.pl; Tel.: +48-71-770-30-66
}

Citation: Kałuża, A.; Szczykutowicz,

J.; Ferens-Sieczkowska, M.

Glycosylation: Rising Potential for Prostate Cancer Evaluation. Cancers 2021, 13, 3726. https://doi.org/

$10.3390 /$ cancers13153726

Academic Editor: Sandra J. van Vliet

Received: 25 June 2021

Accepted: 21 July 2021

Published: 24 July 2021

Publisher's Note: MDPI stays neutral with regard to jurisdictional claims in published maps and institutional affiliations.
Simple Summary: Aberrant protein glycosylation is a well-known hallmark of cancer and is associated with differential expression of enzymes such as glycosyltransferases and glycosidases. The altered expression of the enzymes triggers cancer cells to produce glycoproteins with specific cancer-related aberrations in glycan structures. Increasing number of data indicate that glycosylation patterns of PSA and other prostate-originated proteins exert a potential to distinguish between benign prostate disease and cancer as well as among different stages of prostate cancer development and aggressiveness. This review summarizes the alterations in glycan sialylation, fucosylation, truncated O-glycans, and LacdiNAc groups outlining their potential applications in non-invasive diagnostic procedures of prostate diseases. Further research is desired to develop more general algorithms exploiting glycobiology data for the improvement of prostate diseases evaluation.

\begin{abstract}
Prostate cancer is the second most commonly diagnosed cancer among men. Alterations in protein glycosylation are confirmed to be a reliable hallmark of cancer. Prostate-specific antigen is the biomarker that is used most frequently for prostate cancer detection, although its lack of sensitivity and specificity results in many unnecessary biopsies. A wide range of glycosylation alterations in prostate cancer cells, including increased sialylation and fucosylation, can modify protein function and play a crucial role in many important biological processes in cancer, including cell signalling, adhesion, migration, and cellular metabolism. In this review, we summarize studies evaluating the prostate cancer associated glycosylation related alterations in sialylation, mainly $\alpha 2,3$-sialylation, core fucosylation, branched N-glycans, LacdiNAc group and presence of truncated O-glycans (sTn, sT antigen). Finally, we discuss the great potential to make use of glycans as diagnostic and prognostic biomarkers for prostate cancer.
\end{abstract}

Keywords: glycosylation; glycans; prostate cancer; prostate specific antigen; biomarkers

\section{Introduction}

Prostate cancer was the second most commonly occurring cancer and the fifth leading cause of cancer death among men in 2020 [1,2]. In 1986, prostate-specific antigen (PSA) was approved by the United States Food and Drug Administration (FDA) to screen men for prostate cancer (PCa). PSA is present in small quantities in the serum of men with a healthy prostate (up to $2.5 \mathrm{ng} / \mathrm{mL}$ ), whereas a concentration above $4 \mathrm{ng} / \mathrm{mL}$ is considered indicative of prostate cancer or benign prostatic hyperplasia (BPH) $[3,4]$. Frequently, PSA screening for prostate cancer has limited sensitivity and specificity, which can lead to overdiagnosis and overtreatment of indolent disease, resulting in unnecessary, invasive biopsy and treatments for non-aggressive cancers [5,6]. Hence, in the following years serum PSA screening in association with digital rectal exam (DRE) and Gleason scoring of prostate biopsy samples was approved by the FDA for the early detection of prostate cancer [7]. Subsequent approaches for refining the specificity and sensitivity of the serum PSA test involved calculating the proportion of free PSA (fPSA) to total PSA (tPSA), and PSA complexed with alpha-1-antichymotrypsin and $\alpha 2$-macroglobulin to total PSA [7], as 
well as focusing on the individual molecular forms of PSA such as proPSA, benign PSA, and intact PSA. A multifactorial PSA test, such as the Prostate Health Index (PHI) and the four-kallikrein panel (4Kscore), can improve diagnostic accuracy but has limited prognostic usefulness, and may miss some aggressive tumors [8-10]. More recently, imaging techniques such as multiparametric magnetic resonance imaging (mpMRI) and prostate-specific membrane antigen (PSMA) positron emission tomography (PET)/computed tomography (CT) have evaluated as a potential tool for staging prostate cancer in men before radical treatment. However, the limitations of both techniques were identified. Detection of clinically significant PCa in multiparametric MRI is changeable and depends on a few factors, including tumor location and volume, Gleason score, moreover the analysis of multiparametric prostate MRI is operator dependent [11]. Meanwhile, the sensitivity of PSMA PET/CT technique for the detection of metastases is reduced, presumably due to limitations in the spatial resolution of detecting small tumor deposits in primary and recurrent prostate cancer [12]. Researchers also compared the clinical utility of prostate cancer antigen 3 (PCA3) with PSA in a serum test [13] and widely examined PSA posttranslational modification such as glycosylation [14-16]. Due to the high importance of glycan alterations observed in prostate cancer, including increased sialylation and core fucosylation, the emergence of truncated O-glycans and branched N-glycans, in this review we discuss the great potential to make use of glycans as diagnostic and prognostic biomarkers for prostate cancer. Our review focuses on PSA, the glycoprotein that has been studied in the most detail so far, but the variety of scientific approaches is remarkable, therefore unfractionated biological material such as whole serum were also considered. Not all glycoepitopes important for prostate cancer proliferation have been observed for PSA, thus analyzing only a selected glycoprotein, a lot of data relevant to the assessment of glycosylation changes in prostate disease may be lost. Therefore, presented work does not provide evident solutions for the selection of glycoepitopes that could effectively act as prognostic biomarkers, the studies available so far do not allow for such far-reaching conclusions.

\section{Action of Androgens in the Prostate Gland}

The biomolecules secreted in prostatic fluid are engaged in the regulation of prostate epithelium homeostasis and the process of ejaculation. The agents that provide these functions are kallikreins, which include PSA and kallikrein-related peptidase 2 (hK2). The others are citrate, an intermediate product of the Krebs cycle, and $\mathrm{Zn}^{2+}$, a chemical element actively stored within the cytoplasm of the prostatic epithelial cells $[17,18]$. Physiological growth and development of prostatic epithelium, as well as the regulation of its secretory functions, depend on the appropriate action of androgen steroid hormones [19]. The action of androgens is mediated via the androgen receptor (AR), a ligand-activated transcription factor and member of the steroid hormone nuclear receptor family, which mediates androgen signaling by binding to androgen response elements (AREs) in both normal prostate tissue and prostate cancer [20-22].

Healthy prostate cells store the largest amount of zinc ions of all soft tissues in the human body. This remarkable property is based on the fact that prostatic epithelial cells retain $\mathrm{Zn}^{2+}$ through androgen-dependent $\mathrm{Zn}^{2+}$ cellular uptake and maintain the cycle in which specific zinc transporters are involved [17,18]. The accumulation of $\mathrm{Zn}^{2+}$ and citrate within the prostate, suppression of the Krebs cycle, and the release of fluid from the gland are regulated by androgens. In prostate tissue, a more potent derivative $5 \alpha$ dihydrotestosterone (DHT), synthesized from testosterone by $5 \alpha$-reductase enzyme, is the primary ligand for the AR [23]. Hundreds of genes have been identified that are regulated via DHT in prostate epithelial cells, many of which are essential genes involved in the maintenance of prostate homeostasis [24,25]. Circulating testosterone level and intraprostatic DHT concentration decrease gradually with ageing, causing the gland to malfunction by reducing its ability to sustain a healthy tissue level of intracellular $\mathrm{Zn}^{2+}$, KLK-secreted proteins and citrate within the prostate liquid. 
Normal prostate epithelial cells display characteristic behaviour in relation to their metabolic pathway. They are programmed to produce citrate, unlike most cells which oxidize it [26]. The inhibition of the Krebs cycle in normal prostate cells results in the accumulation and subsequent secretion of citrate as a component of semen. This distinctive process of citrate production is supported by another specific feature of the prostate epithelial cells: the ability to store high concentrations of zinc, which have been shown to inhibit m-aconitase, the enzyme that catalyses the oxidation of citrate in the Krebs cycle $[27,28]$. Accumulation of zinc in prostate epithelium is driven by an increased amount of the zinc transporter ZIP1 in tissue [27,28]. In normal prostate epithelial cells, through the accumulation of zinc, the Krebs cycle is inhibited, so these cells are energetically inefficient. This leads to an ATP production process different than present in most cells [29]. In contrast, prostate cancer cells reverse this process, leading to reactions that cause zinc loss and citrate oxidation, which is a major change in energy metabolism $[18,28]$. It was discovered long ego that prostate cancer cells do not exhibit the standard Warburg effect, observed in most cancer cells, whereby high glucose uptake and lactate release are considered hallmarks of most tumors [30]. As opposed to most cancer cells that utilize aerobic glycolysis, prostate cancer cells show a higher level of citric acid cycle activity compared to normal cells $[26,28,31]$.

Apart from that, androgens are crucial for the development and metastatic progression of prostate cancer. Undoubtedly, androgen deprivation therapy (ADT) is the widely accepted initial treatment for symptomatic metastatic prostate cancer. In the early stages of diseases ADT is effective, but after 2-3 years the patients may develop castration-resistant prostate cancer (CRPC), which is ultimately lethal [32,33].

\section{Prostatic Inflammation, Benign Prostatic Hyperplasia and Prostate Cancer}

Recent data support the role of chronic prostatic inflammation as a predisposing factor for development of BPH [34] and prostate cancer [35]. Several authors have highlighted the significance of prostatic inflammation in the origin of $\mathrm{BPH}$, pointing out that the prostate is an immunocompetent gland in which a small number of inflammatory cells such as $T$ and B lymphocytes, mast cells and macrophages are physiologically present [36]. In adults, chronic inflammatory prostate infiltrates vary greatly in $\mathrm{BPH}$ and healthy tissues. The most common cells of infiltrates from patients with $\mathrm{BPH}$ are $\mathrm{CD} 19^{+}$or $\mathrm{CD} 20^{+} \mathrm{B}$ lymphocytes, $\mathrm{CD}^{+} \mathrm{T}$ lymphocytes and macrophages [37]. The $\mathrm{B}$ and $\mathrm{T}$ cells as well as macrophages occurring in the adult prostate can contribute to the damage of both epithelial and stromal cells, induce cytokine production and increase the concentration of growth factors that can stimulate an anomalous remodelling process. Interestingly, IL-8 has been suggested as a link between chronic prostate inflammation and the development of BPH. Several studies have indicated significantly elevated IL-8 expression in epithelial prostate cells and emphasized that this can trigger the expression of fibroblast growth factor (FGF) and stromal-epithelial growth factor signaling and subsequently induce abnormal proliferation of prostatic cells [38]. In consequence, tissue damage can initiate a chronic wound healing process that can induce prostate enlargement, potentially resulting in $\mathrm{BPH}$ [36].

\section{Biology of Prostate-Specific Antigen}

Prostate fluid is a rich source of prostate-derived proteins that can be used for biomarker discovery in a number of prevalent benign and malignant prostatic diseases including prostatitis, benign prostatic hyperplasia and prostate cancer. Several glycosylated proteins have been accepted as cancer biomarkers by the FDA, including prostate-specific antigen $[39,40]$. Prostate-specific antigen (PSA), also known as human kallikrein 3 (KLK3), is currently widely used as the gold standard biomarker for screening and diagnosis of prostate cancer [4]. PSA is an organ-specific glycoprotein, secreted by the epithelium and periurethral glands. PSA occurs as a 237-amino acid serine protease with chymotrypsinlike activity, and its transcription is regulated by androgens [41,42]. PSA is secreted as an inactive proenzyme (proPSA) into seminal fluid, which during the liquefaction process is 
converted by kallikrein-related peptidase 2 to a $33 \mathrm{kDa}$ mature active form $[3,43,44]$. In the early stage of prostate cancer development, disruption of the basal cell layer and the basement membrane of the prostate epithelium results in leakage of PSA into the peripheral circulation, and this circulating blood form of PSA is identified in the early detection tests for prostate cancer [3]. The serum PSA level increases with the clinical severity of disease and is proportional to tumor volume, whereas after radical prostatectomy its level in serum reaches undetectable values [41,45]. Schroeder et al. showed that PSA-based screening of prostate cancer reduced the rate of death by $20 \%$ but simultaneously was correlated with a high degree of overdiagnosis [46].

PSA has a single N-glycosylation site at asparagine (Asn-69), verified in X-ray crystal structures $[47,48]$. In 2013, the results of a comprehensive multi-laboratory ABRF study examining N-glycosylation of Asn-69 in healthy donors were announced, and they made it possible to describe the structure of glycans attached to PSA $[3,48,49]$. The most abundant glycans identified were four biantennary glycan structures, consisting of three mannose, two galactose subunits, and four $\beta-\mathrm{N}$-acetylglucosamine residues, estimated to comprise approximately $80 \%$ of the total number of PSA-related glycans. These all have one or two terminal sialic acid residues and the presence or absence of a core fucose. Two dominant hybrid structures have also been reported [3,48,49].

\section{Glycosylation Changes in Cancer}

Protein glycosylation is a post-translational process that enhances molecular heterogeneity as well as functional diversity within cell populations. Tumor cells show a wide range of glycosylation rearrangement in relation to their unchanged counterparts. Hakomori and Kannagi were the first to postulate the two main mechanisms underlying the cancer-associated changes of carbohydrate structures, called incomplete synthesis and neo-synthesis [50]. The incomplete biosynthesis pathway, typical for the early stages of a tumor, is the result of defective synthesis of typical glycans present in normal epithelial cells, leading to the synthesis of truncated structures such as short-chain O-GalNAc glycans (Tn, T, sialyl-Tn, and sialyl-T antigens). In contrast, neo-synthesis occurs extensively in advanced stages of cancer, and is associated with the induction of some genes involved in the glycosylation pathway, which results in de novo expression of antigens such as Lewis blood group related antigens (Le) and their sialylated counterparts: sialyl Lewis A (sLe ${ }^{\mathrm{a}}$ ) and sialyl Lewis X (sLe ${ }^{\mathrm{X}}$ ) antigens (Figure 1) [50,51]. Altered expression of glycans may result from several biological factors: (1) overexpression or underexpression of the relevant glycosyltransferases in the Golgi apparatus, (2) changed glycosidase activity, (3) alterations in tertiary peptide backbone composition, and (4) the availability and sufficiency of the sugar nucleotide donors and cofactors [52-54]. The presence and molecular density of the glycans affect the half-life of many different types of membrane receptor proteins, including glucose transporters, cytokine receptors, transforming growth factor beta (TGF- $\beta$ ) and epidermal growth factor receptor (EGFR), which are involved in tumor formation and cell migration associated with cancer progression [54-56]. 


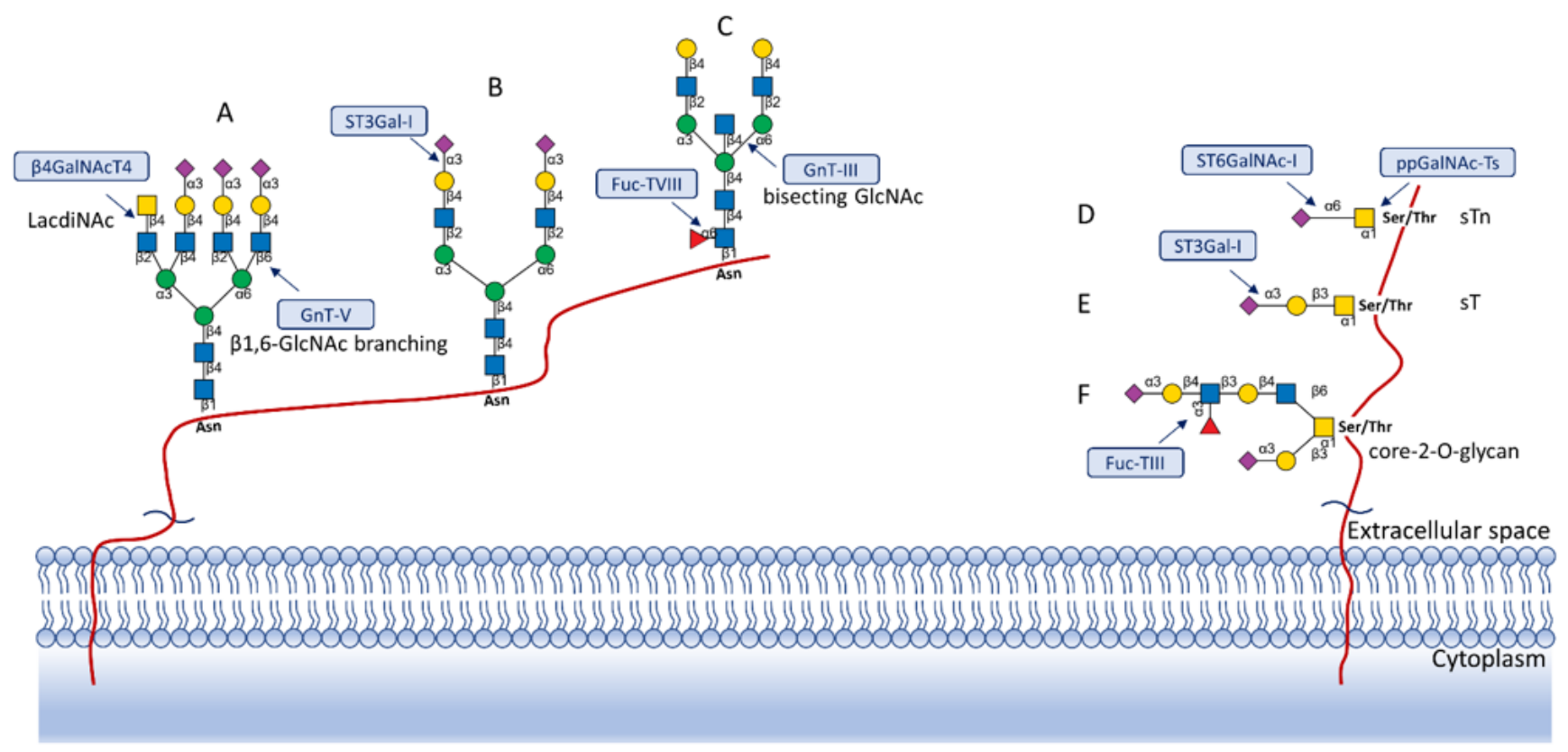

GIcNAc $\square$ GalNAc $\bigcirc$ Man $\bigcirc$ Gal $\boldsymbol{\Delta}$ Fuc $\diamond$ Sialic acid

Figure 1. Overexpressed glycan structures typical for PCa. (A) Highly branched (tetra-antennary) N-glycan with LacdiNAc motif; (B) Biantennary N-glycan terminated with $\alpha 2,3$-linked SA; (C) Biantennary N-glycan with core fucose and bisecting GlcNAc; (D) sTn truncated O-glycan; (E) sT O-glycan antigen; (F) core-2-O-glycan with sLe ${ }^{\mathrm{X}}$ antigen. Blue boxes indicate glycosyltransferases involved in the synthesis of particular structures.

\section{Sialylated N-Glycans}

Sialylated glycans are the ligands of various proteins involved in crucial biological processes; cell surface sialylated glycans are engaged in the immune response, signal transduction and embryonic development. The sialic acid residues operate as receptors for specific ligands, such as siglecs and selectins $[57,58]$. Many reports have also stated that sialylated glycans are involved in oncogenesis and malignant progression [58]. The transformation of healthy cells into heterogeneous cancer cells is accompanied by the appearance of an abnormal sialylation pattern, which is reflected in a large group of sialylated glycoproteins secreted by tumor cells $[58,59]$. One of the decisive glycomic features associated with malignant and metastatic progression is the presence of N-glycans terminated with $\alpha 2,6-\mathrm{N}$-acetylneuraminic acid (Neu5Ac) residues, controlled by the action of $\beta$-galactoside- $\alpha 2,6$-sialyltransferase I (ST6Gal-I). Expression of this enzyme is modified in various malignancies, including prostate, breast and ovarian cancer [60-62]. The presence of $\alpha 2,6$-linked sialic acids on tumor cells is crucial because $\alpha 2,6$-sialylation can execute alternative biological outcomes compared to $\alpha 2,3$-sialylation. One accurate example is the impact of $\alpha 2,6$-sialylation on galectin-dependent cell behaviours. Numerous studies indicate that $\alpha 2,6$-sialylation of galactose acts as a general inhibitor of galectin binding, in contrast to $\alpha 2,3$-sialylation with various binding effects to some particular galectins. Therefore, glycans capped with $\alpha 2,6$-sialic acid globally act as a significant negative regulator of many key galectin functions. One of the important activities of cell surface $\alpha 2,6$-sialyation is to suppress the binding of pro-apoptotic galectins, at the same time inducing cancer cell survival $[63,64]$.

Additionally, elevated sialylation in cancer can be related to the formation of polysialic acid, which is associated with several types of cancers and is often present in high-grade tumors $[58,65]$. Other main sialylated antigens associated with cancer are $\mathrm{sLe}^{\mathrm{a}}$ and $s \mathrm{se}^{\mathrm{x}}$. These have been shown to be remarkably expressed in many malignant tumors, including hepatic, renal and breast cancers [66]. Additionally, sLe ${ }^{\mathrm{x}}$ antigen expression level has been associated with a diminished chance of survival for prostate cancer patients [67]. $\mathrm{SLe}^{\mathrm{x}}$ and its isomer sLe ${ }^{\mathrm{a}}$ are crucial recognition determinants for selectins, vascular cell 
adhesion molecules belonging to a large family of C-type lectins. In the process of inflammation, selectins mediate the first stage of leucocytes' adhesion to the endothelium during leucocyte extravasation [68]. In cancer cells, $\mathrm{sLe}^{\mathrm{x}}$ interactions with selectins regulate the metastatic process by tethering platelet-tumor cell emboli and promoting their arrest on the endothelium, therefore contributing to malignant behaviour and the progression of metastasis [69].

Over the years, PSA glycosylation changes have been analysed by mass spectrometry, and the level of $\alpha 2,3$-linked sialic acid was reported to be remarkably different in prostate cancer patients compared to a control group, stressing the importance of PSA sialylation in distinguishing cancer patients from healthy men (Figure 1B) $[14,16,70]$. In patients with prostate cancer, serum PSA contains increased levels of $\alpha 2,3$-linked sialic acid connected to the terminal galactose residue compared to healthy individuals [14,71]. Additionally, Ohyama et al. detected that binding of prostate cancer related PSA to Maackia amurensis lectin specific for $\alpha 2,3$-linked sialic acid was more intense than binding of PSA from healthy individuals [72]. Serum glycoproteins of prostate cancer patients showed increased levels of $\alpha 2,3$-linked sialic acid in relation to serum of patients with benign prostatic hyperplasia. The authors suggested that this feature can be used to predict the Gleason score with greater sensitivity and specificity than PSA concentration, used to date [73].

In metastatic prostate cancer two main forms of PSA were detected in the serum: a free form and alpha-1-antichymotrypsin (ACT)-complexed PSA. Both were characterized by mostly sialylated biantennary glycan structures, but the presence of several multi-antennary complex structures was also observed [14]. Yoneyama et al. developed a more sensitive diagnostic PSA test, in which they used a magnetic microbead-based immunoassay, that directly measured the amount of $\alpha 2,3$-linked sialic acid on the free serum PSA. The new assay showed a sensitivity of $95 \%$ and a specificity of $72 \%$ in a measurement carried out on a cohort of over 300 serum samples, from patients who underwent biopsy, including $138 \mathrm{PCa}$ and 178 non-PCa patients with a PSA level less than $10.0 \mathrm{ng} / \mathrm{mL}$ [16]. This solution was more sensitive and accurate than the conventional PSA level and the free PSA-percent tests in the diagnosis of prostate cancer. Another study conducted in $13 \mathrm{BPH}$ and 34 prostate cancer patients' sera (including 17 Gleason grade 5 and 17 Gleason grade 7 samples), which considered N-glycans from the whole serum glycoproteins, indicated that tetra-antennary tetra-sialylated $\mathrm{N}$-linked oligosaccharide levels were higher in the serum samples from patients with Gleason score 7 compared to Gleason score 5. Conversely, levels of tetra-antennary tetra-sialylated glycans with terminal fucose and tri-antennary tri-galactosylated glycans were significantly lower in serum from patients with a Gleason score of 7 compared to a Gleason score of 5 [73]. Moreover, the detection of $\alpha 2,3-$ linked sialic acid PSA glycoforms combined with the PHI in a cohort of 79 patients showed $100 \%$ sensitivity and $94.7 \%$ specificity. The proposed analysis proved superior to PSA to distinguish aggressive prostate cancer from low-risk and benign disease (Table 1) [74]. 
Table 1. Summary of sialylated N-glycan alterations in prostate cancer.

\begin{tabular}{|c|c|c|c|c|}
\hline Type of Glycans & Structure & Sample Groups & Main Results & $\begin{array}{l}\text { Author Year } \\
\text { References }\end{array}$ \\
\hline \multirow{7}{*}{$\alpha 2,3$-sialylated } & \multirow{7}{*}{$\begin{array}{cc}9 & 9 \\
0 & 9 \\
1 & 9 \\
0 & 0\end{array}$} & $\begin{array}{l}\text { Serum of PCa patients vs. serum of } \\
\text { non-PCa patients }\end{array}$ & $\begin{array}{c}\text { Serum } \alpha 2,3 \text {-linked sialic acid of PSA in PCa group was } \\
\text { significantly higher than in non-PCa group }\end{array}$ & $\begin{array}{c}\text { Yoneyama } 2014 \\
{[16]}\end{array}$ \\
\hline & & $\begin{array}{l}\text { PCa serum vs. control serum } \\
\text { (healthy men) }\end{array}$ & $\begin{array}{c}\text { Level of } \alpha 2,3 \text {-linked sialic acid of PSA from prostate } \\
\text { cancer serum was increased compared to } \\
\text { healthy individuals }\end{array}$ & $\begin{array}{c}\text { Pihikova } 2016 \\
\text { [70] }\end{array}$ \\
\hline & & BPH serum vs. PCa serum & $\begin{array}{c}\text { Significant increase in } \alpha 2,3-\text { linked sialic acid from total } \\
\text { serum glycoproteins in PCa group comparing with } \\
\text { BPH group was detected }\end{array}$ & Saldova 2011 [73] \\
\hline & & $\begin{array}{l}\text { BPH serum, low-risk PCa serum, } \\
\text { intermediate-risk PCa serum, and } \\
\text { high-risk PCa serum samples }\end{array}$ & $\begin{array}{c}\text { There was a significant increase of } \alpha 2,3 \text {-sialylated PSA } \\
\text { in the group of high-risk PCa patients compared with } \\
\text { the intermediate-risk PCa, low-risk PCa, and } \\
\text { BPH groups }\end{array}$ & Llop 2016 [75] \\
\hline & & BPH serum vs. PCa serum & $\begin{array}{c}\text { Serum } \% \alpha 2,3 \text {-sialic acid of PSA was significantly } \\
\text { higher in patients with PCa compared to BPH patients }\end{array}$ & Ishikawa 2017 [76] \\
\hline & & BPH serum vs. PCa serum & $\begin{array}{l}\text { The combination of } \% \alpha 2,3-\text { SA PSA and PHI } \\
\text { differentiates high-risk PCa patients from the low and } \\
\text { intermediate-risk PCa patients }\end{array}$ & $\begin{array}{c}\text { Ferrer-Batalle } 2017 \\
\text { [74] }\end{array}$ \\
\hline & & $\begin{array}{l}\text { PCa urine samples with varied } \\
\text { Gleason scores }\end{array}$ & $\begin{array}{l}\text { Highly sialylated urinary N-glycans were upregulated } \\
\text { in metastatic cancer patients }\end{array}$ & $\begin{array}{l}\text { Yang } 2017 \\
\text { [77] }\end{array}$ \\
\hline Tetra-antennary tetrasialylated & & $\begin{array}{c}\text { BPH serum vs. PCa serum }(17 \\
\text { Gleason grade } 5 \text { and } 17 \text { Gleason grade } \\
7 \text { samples })\end{array}$ & $\begin{array}{l}\text { Tetra-antennary tetra-sialylated glycans were } \\
\text { increased in the serum samples from patients with } \\
\text { Gleason score } 7 \text { compared to Gleason score } 5\end{array}$ & $\begin{array}{c}\text { Saldova } 2011 \\
{[73]}\end{array}$ \\
\hline
\end{tabular}


Table 1. Cont

\begin{tabular}{|c|c|c|c|c|}
\hline Type of Glycans & Structure & Sample Groups & Main Results & $\begin{array}{l}\text { Author Year } \\
\text { References }\end{array}$ \\
\hline $\begin{array}{l}\text { Tri-antennary, tri-galactosylated } \\
\text { tri-sialylated with and without core } \\
\text { fucose residue }\end{array}$ & 999 & $\begin{array}{l}\text { Indolent, significant, aggressive PCa } \\
\text { according Epstein's criteria }\end{array}$ & $\begin{array}{l}\text { A decreased amount of tri-antennary, } \\
\text { tri-galactosylated tri-sialylated glycans with and } \\
\text { without core fucose residue corresponding to the } \\
\text { transition of PCa from indolent state through } \\
\text { significant and aggressive disease }\end{array}$ & $\begin{array}{l}\text { Gilgunn } 2020 \\
{[78]}\end{array}$ \\
\hline $\begin{array}{l}\text { Sialylated glycoforms bearing } \\
\text { GalNAc moieties }\end{array}$ & $\stackrel{\varphi}{\square}$ & $\begin{array}{l}\text { Serum PCa vs. standard SP PSA of } \\
\text { healthy men }\end{array}$ & $\begin{array}{l}\text { Serum PSA sialylated glycoforms bearing GalNAc } \\
\text { moieties were heightened in aggressive PCa patients }\end{array}$ & $\begin{array}{c}\text { Gratacós-Mulleras } 2020 \\
\text { [79] }\end{array}$ \\
\hline
\end{tabular}


The most recent study considering whole serum N-linked glycans in various prostate cancer stages aimed to investigate whether an altered glycosylation pattern could differentiate distinct forms of prostate cancer, including indolent, significant, and aggressive PCa. N-glycan profiling was performed on 117 prostate cancer serum samples using an automated, high-throughput analytical platform, which exploits ultra-performance liquid chromatography for high resolution separation of N-glycans. The results revealed a decreased amount of tri-antennary, tri-galactosylated tri-sialylated glycans with and without core fucose residues, corresponding to the transition of PCa from the indolent stage through significant and aggressive disease. Additionally, an increase in hybrid, oligomannose, bisecting GlcNAc and monoantennary glycans was observed (Table 1) [78].

Another interesting investigation regarded the main sialylated PSA glycoforms from the serum of aggressive PCa patients in relation to standard PSA from seminal plasma of healthy men. Exploiting Sambucus nigra affinity chromatography, the $\alpha 2,6$-linked sialic acid glycoforms were separated from $\alpha 2,3$-linked glycoforms, then PSA N-glycans were analysed by hydrophilic interaction liquid chromatography. The results indicated that levels of serum PSA sialylated glycoforms bearing GalNAc moieties (LacdiNAc) were raised in aggressive PCa patients. Concomitantly, levels of disialylated core fucosylated biantennary structures with $\alpha 2,6$-linked sialic acid, which were previously indicated as major PSA glycoforms characteristic for standard PSA from healthy men, were significantly lowered in aggressive PCa (Table 1) [79].

\section{Fucosylated N-Glycans}

Fucosylated glycans are synthesized by a series of fucosyltransferases. The modification generally occurs as core fucosylation and terminal fucosylation, the latter including specific Lewis blood group antigens such as $\mathrm{Le}^{\mathrm{x}}, \mathrm{Le}^{\mathrm{y}}, \mathrm{Le}^{\mathrm{a}}$, and $\mathrm{Le}^{\mathrm{b}}$. The core fucosylation of protein relies on addition of a fucose residue to the innermost $\mathrm{N}$-acetylglucosamine (GlcNAc) residue of N-glycans via an $\alpha 1,6$-linkage, and is catalysed by fucosyltransferase Fuc-TVIII (Figure 1C), encoded by the FUT8 gene [80]. Altered expression of FUT8 and FUT6 is an important feature in several cancers such as high-grade prostate cancer and breast cancer [80,81]. The FUT6 gene encodes $\alpha 1,3$-fucosyltransferase and is upregulated in distant metastases. It was also reported that the product of this gene can participate in metastasis to bones [82]. Furthermore, expression of FUT6 might trigger prostate cancer cell trafficking through an E-selectin-dependent mechanism [83,84]. Overexpression of FUT8 has been recently linked with aggressive and castrate-resistant prostate cancer, as well as being associated with a poor prognosis for patients $[85,86]$. More recent data indicate that FUT8 is involved in controlling the function of cancer cell membrane receptors [87]. Core fucosylation transforms cell surface molecules as well as the tumor microenvironment, and thus the extracellular matrix and growth factors, supporting cancer progression. FUT8 promotes cancer cell invasiveness by remodelling the core fucosylation of the TGF- $\beta$ receptor $[88,89]$, as the presence of core fucose strongly affects the binding affinity of the TGF- $\beta$ receptor and thus TGF- $\beta$ induced epithelial-mesenchymal transformation (EMT) [90,91].

In the serum of prostate cancer patients increased core fucosylation of glycans has been found, compared to patients with $\mathrm{BPH}$ as well as men without known prostatic disease. These findings suggest that core fucosylation is associated with disease progression [73,92,93]. Saldova et al. established a high-throughput HPLC assay and used it for quantitative analysis of N-glycans from the whole serum glycoproteins of BPH and prostate cancer samples. Additionally, the samples were split into low and higher grade Gleason groups. A significant increase in core-fucosylated biantennary glycans in prostate cancer related to BPH was observed, but no changes in these glycans were associated with Gleason scores (Table 2) [73]. 
Table 2. Summary of fucosylated, bisected, tri- and tetra-antennary N-glycan alternations in prostate cancer.

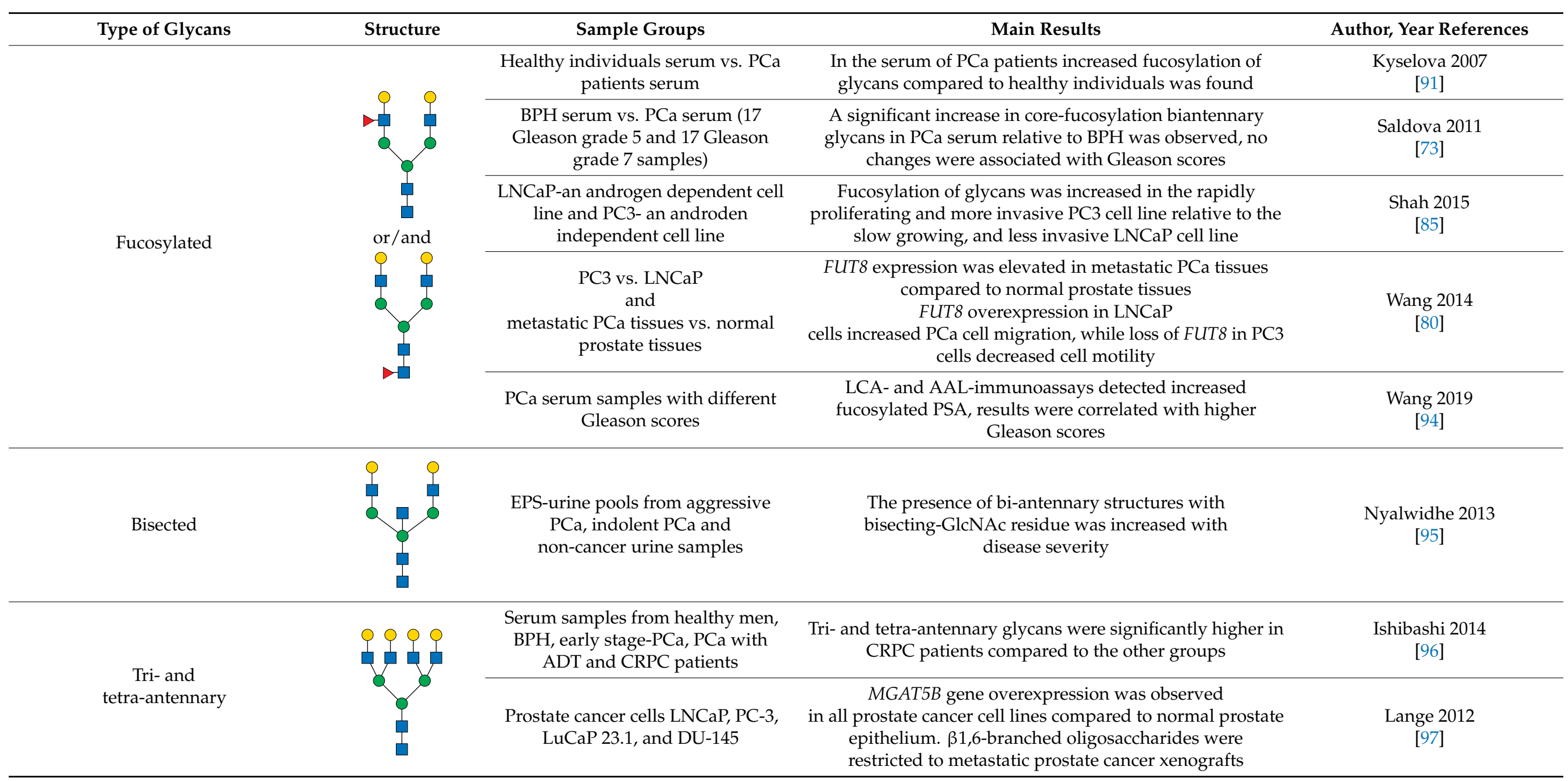


Table 2. Cont.

Type of Glycans

LacdiNAc motif
Structure

Sample Groups

Normal seminal fluid and prostate cancer cells LNCaP

The amount of the LacdiNAc moieties was increased in normal SP PSA

Abundance of multisialylated LacdiNAc structures was significantly upregulated in the PCa patients compared to the $\mathrm{BPH}$ group

In prostate cancer the upregulation of the $\beta 4 \mathrm{GalNAcT} 4$ was observed, and were correlated with the overexpression of the LacdiNAc groups for PCa-derived PSA

Seminal fluid, serum of BPH and

PCa patients, and LNCaP cell line

The LacdiNAc-PSA immunoassay allowed for distinction

between PCa and BPH within the PSA gray zone

BPH serum vs. PCa serum

LacdiNAc-PSA were significantly higher in PCa sera than in BPH sera

Author, Year References

Peracaula 2003

Haga 2019

Fukushima 2010

\section{Kaya 2015}

[100] 
Studies utilizing the two prostate cancer cell lines LNCaP and PC3 have shown that fucosylation of glycans is increased in the rapidly proliferating and more invasive PC 3 cell line compared to the slow growing, less invasive LNCaP cell line [85]. Wang et al. detected expression of $\alpha 1,6$-fucosyltransferase solely in PC3, and not in LNCaP cells. Afterwards the authors found that FUT8 expression was elevated in metastatic PCa tissues compared to normal prostate tissues. Using PC3 and LNCaP cells as models, they also confirmed that FUT8 overexpression in LNCaP cells increased PCa cell migration, while the silencing of FUT8 expression in PC 3 cells reduced cell motility. These results suggest the association of FUT8 with aggressive prostate cancer (Table 2) [91,101].

In a recent study Clark et al. evaluated the effect of altered $\alpha 1,6$-fucosyltransferase expression on extracellular vesicles (EVs) in a prostate cancer cell model. They found that increased cellular expression of FUT8 can reduce the number of vesicles secreted by prostate cancer cells and simultaneously enhance the protein abundance correlated with cell motility and prostate cancer metastasis. Overexpression of FUT8 can also cause changes in glycans presented on EV-derived glycoproteins [101]. Wang and co-workers developed a quantitative lectin immunoassay using Lens culinaris agglutinin (LCA) and Aleuria aurantia lectin (AAL) to evaluate the level of PSA fucosylated glycoforms in serum samples from prostate cancer patients with different Gleason scores. The results demonstrated that both LCA and AAL immunoassays identified an increased level of fucosylated serum PSA. These results were concomitantly correlated with higher Gleason scores. Finally, the authors concluded that the determined fucosylated PSA forms could be valuable biomarkers to differentiate between aggressive and non-aggressive prostate cancer (Table 2) [94].

\section{Branched N-Glycans}

During malignant transformation and cancer progression, a frequently occurring change in the glycosylation pattern is the increased expression of complex $\beta 1,6$-branched $\mathrm{N}$-glycans [102]. The raised level of GlcNAc-branching N-glycans is a result of increased activity of mannoside $\mathrm{N}$-acetylglucosaminyltransferase $5(\mathrm{GnT}-\mathrm{V})$, which is encoded by the MGAT5 gene, often activated in cancer cells [59]. Activity of GnT-V leads to the formation of complexed tri- and tetra-antennary structures (Figure 1A), which can affect the stability, functional activity and half-life of proteins, as well as membrane dynamics $[61,103]$. Furthermore, branched N-glycans can be modified via $\beta 1$,4-galactosyltransferases $(\beta 1,4-$ GalTs), thus elongated with poly-N-acetyllactosamine repeats, and finally capped with sialic acid or fucose. Poly-N-acetyllactosamine moieties are ligands for galectins, a family of evolutionarily conserved carbohydrate-binding proteins. These lectins bind glycans with high avidity and affinity, forming multivalent galectin-glycan lattices that control glycoprotein clustering and endocytosis, to regulate receptor signaling and activation [104]. Galectins play an essential role in cancer, participating in neoplastic transformation, survival of cancer cell, angiogenesis and tumor metastasis $[59,105]$. In contrast to the function of GnT-V, GnT-III catalyses the attachment of bisecting GlcNAc N-glycans via a $\beta 1$,4-linkage (Figure 1C), inhibiting further conversion and extension of the glycan, as seen in $\beta 1$,6-branched structures. GnT-III counteracts the role of GnT-V in the neoplastic process by participating in the inhibition of cancer metastasis [59].

Numerous studies have indicated that $\mathrm{N}$-acetylglucosaminyltransferase $\mathrm{V}$ is an important tumorigenesis- and metastasis-associated enzyme in prostate cancer [106]. Lange et al. reported that $\beta 1,6-$ GlcNAc tri- and tetra-branched N-glycans were increased in cell line xenograft mouse models of prostate cancer (Table 2) [97]. Additionally, it was found that patients with castration-resistant prostate cancer had both overexpressed transcription levels of N-glycan branching enzymes and increased tri- and tetra-antennary N-glycans [91,96]. Slightly different observations were reported for direct expressed-prostatic secretion (EPS) and EPS urine samples. A decline in the amount of tri- and tetra-antennary glycans in advanced prostate cancer samples with a Gleason score of 8 and 9 was detected, and at the same time many biantennary structures with a bisecting-GlcNAc residue were observed, suggesting antimetastatic activity of GnT-III [95]. In some recent research it has been empha- 
sized that changes in branched N-glycans can help to distinguish between BPH and prostate cancer, and furthermore increased levels of serum tri- and tetra-antennary $\mathrm{N}$-glycans can be clinically useful for predicting castrate-resistant prostate cancer (Table 2) [96]. In a recent study, tetra-antennary N-glycans were identified as part of a biomarker panel to refine the distinction of patients with indolent and aggressive prostate cancer and predict patient survival [107].

\section{LacdiNAc Structures}

In general, LacdiNAc structures are rarely observed in normal mammalian cells, while their frequency is significantly increased in prostate, ovarian, and pancreatic cancers $[98,108,109]$. The terminal modification of $\mathrm{N}$-glycans results from the $\beta 4$-linkage of $\mathrm{N}$-acetylgalactosamine to $\mathrm{N}$-acetylglucosamine to form the LacdiNAc unit (GalNAc $\beta 1 \rightarrow 4$ GlcNAc). Two human $\beta 4$ $\mathrm{N}$-acetylgalactosaminyltransferases ( $\beta 4$ GalNAcTs) - $\beta 4$ GalNAcT3 and $\beta 4$ GalNAcT4-are involved in biosynthesis of the LacdiNAc motif (Figure 1A). Although the enzymes have high sequence homology and similar substrate specificities, they present different tissue distribution: the B4GALNT3 gene is mainly expressed in the human testis, stomach and colon, while the B4GALNT4 gene is expressed in the human brain and ovary [109].

LacdiNAc structures have been documented for PSA N-glycans purified from seminal plasma of healthy individuals and from the human prostate cell line LNCaP. The amounts of the LacdiNAc moieties were increased in PSA obtained from prostate cancer cells $[71,109]$. Furthermore, the occurrence of LacdiNAc groups on PSA has been observed in numerous studies using Wisteria floribunda agglutinin (WFA) [98-100,110]. Interestingly, in prostate cancer the upregulation of $\beta 4$ GalNAcT4 was observed, while no changes were noted for $\beta 4$ GalNAcT3 $[99,109]$. Additionally, a correlation between enzyme upregulation and overexpression of LacdiNAc epitopes in prostate cancer derived PSA was found (Table 2) [99]. When prostate cancer and benign prostatic hyperplasia PSA were compared, BPH patients' glycoproteins contained predominantly terminally sialylated, complex-type biantennary N-glycans, whereas PSA from patients with prostate cancer presented an increased amount of similar biantennary complex-type glycans, but with one LacdiNAc unit, only partially sialylated [109]. Haga and co-workers observed that abundance of multiple sialylated LacdiNAc structures was significantly upregulated in PCa patients compared to the BPH group, and further established a new, highly sensitive PCa-specific diagnostic model: the "PSA G-index". It is based on the relative abundance of the two diand tri-sialylated LacdiNAc glycoforms. Both above-mentioned PSA glycoforms showed a significant correlation with Gleason scores. In the same study, histochemical staining analysis with WFA lectin showed that PCa cells overexpressed glycoproteins containing LacdiNAc moieties (Table 2) [98]. The low sensitivity of tests developed so far encourages the use of a combination of several markers in the assay, suggesting that such a combination could ultimately constitute a biomarker panel for prostate cancer detection, as proposed by Yoneyama et al. To identify clinically significant prostate cancer (CSPC), they evaluated the amount of LacdiNAc-glycosylated prostate-specific antigen (LDN-PSA) and LDN-PSA normalized by prostate volume (LDN-PSAD). During the experiment, they measured LDN-PSA, total PSA, and ratio of free PSA to total PSA values in 718 men who underwent a prostate biopsy and in 174 prostate cancer patients who underwent radical prostatectomy. In the cohort of prostate biopsy patients LDN-PSAD demonstrated significantly higher clinical performance to discriminate CSPC compared with LDN-PSA, PSAD, total PSA and free/total PSA ratio. The authors concluded that LacdiNAc-glycosylated PSA is significantly more efficient than the conventional PSA test in identifying patients with CSPC [111].

\section{Truncated O-Glycans}

Biosynthesis of O-glycans is initiated by transfer of a single $\mathrm{N}$-acetylgalactosamine residue to serine or threonine by polypeptide N-acetylgalactosaminyltransferases ppGalNAcTs (GALNTs), to form a simple Tn antigen [112]. In subsequent stages enzymatic extension 
of Tn antigen with galactose builds core $1 \mathrm{O}$-glycans (T antigen), which can be further extended with $\beta 1,6-\mathrm{N}$-acetylglucosamine to produce core 2 O-glycans (Figure 1E,F). GCNT1 is reported to be involved in the formation of core 2 branched O-glycans and in synthesis of the cancer-associated antigen sLe ${ }^{x}[113,114]$. Increased GCNT1 expression has been linked to prostate cancer progression and is a predictor of recurrence after radical prostatectomy $[114,115]$. Expression of both GCNT1 and the sLe ${ }^{\mathrm{x}}$ antigen is controlled by androgens in prostate cancer cells. Moreover, $\mathrm{sLe}^{\mathrm{x}}$ is the major sialylated antigen related to poor prognosis and metastasis in PCa $[48,113]$.

Alternatively, attachment of the $\mathrm{N}$-acetylneuraminic acid molecule to the Tn antigen can generate sialo-Tn antigen (sTn) (Figure 1D). Formation of the sTn antigen is regulated by expression of sialyltransferase ST6GalNAc-I. Such modifications are frequently dysregulated, often occur during the neoplastic transformation process and are associated with numerous malignancies, including breast, colorectal, ovarian and gastric cancers $[116,117]$. Munkley et al. found that expression of the sialyltransferase ST6GalNAc-I and the cancer-associated sialyl-Tn antigen is regulated by androgens in prostate cancer cells, and is involved in reducing cell adhesion, leading to transformation towards a more mesenchymal-like cell phenotype in a mouse model of prostate cancer, during a process termed epithelial-mesenchymal transition (EMT) [118,119]. This fact is worth emphasizing, as the sTn antigen was detected in half of all high-grade prostate cancer tissue samples from patients with diagnosed prostate disease [118,120]. Additionally, ST6GalNAc-I expression was found to be increased in primary prostate tumors and decreased in metastatic tissue compared to benign prostate tissue. Several studies have shown that increased expression of sialylated Tn antigens inhibits formation of a solid tumor mass and promotes cell detachment from the tumor (Table 3) [118,121]. These results indicate that ST6GalNAc-I may play a significant role in tumor cell invasion and migration $[118,119]$. In earlier research of Arai and co-workers, the presence of sTn in the serum or tumor tissue biopsy was correlated with cancer progression and worse survival outcomes in prostate cancer patients. Additionally, the expression of sialyl-Tn MUC-1, a protein that plays a protective role for the mucosal epithelial surface [122], was negatively correlated with survival outcomes and positively correlated with higher serum PSA levels (Table 3) [123].

Table 3. Summary of truncated O-glycan alternations in prostate cancer.

\begin{tabular}{|c|c|c|c|c|}
\hline Type of Glycans & Structure & Sample Groups & Main Results & $\begin{array}{l}\text { Author, Year } \\
\text { References }\end{array}$ \\
\hline \multirow[b]{2}{*}{ sialyl-Tn (sTn) antigen } & \multirow[b]{2}{*}{ 口 } & $\begin{array}{l}\text { Prostate cancer } \\
\text { specimens vs. normal } \\
\text { prostate specimens }\end{array}$ & $\begin{array}{l}\text { The presence of sialyl-Tn MUC-1 was } \\
\text { correlated with cancer progression, } \\
\text { positively correlated with higher serum } \\
\text { PSA level in PCa patients, and negatively } \\
\text { correlated with survival outcomes }\end{array}$ & $\begin{array}{l}\text { Arai } 2005 \\
\quad[123]\end{array}$ \\
\hline & & $\begin{array}{l}\text { primary and } \\
\text { metastatic tumors }\end{array}$ & $\begin{array}{l}\text { Expression of sTn was induced by } \\
\text { androgens in prostate cancer cells and is } \\
\text { mediated by ST6GalNAc-I. } \\
\text { ST6GalNAc-I was significantly } \\
\text { up-regulated in primary prostate carcinoma } \\
\text { but relatively down-regulated in } \\
\text { established metastatic tissue. }\end{array}$ & $\begin{array}{c}\text { Munkley } 2015 \\
\text { Munkley } 2016 \\
{[118,119]}\end{array}$ \\
\hline $\begin{array}{l}\text { sialyl-T (sT) } \\
\text { antigen }\end{array}$ & P & $\begin{array}{l}\text { VCaP, LNCaP, DU145, } \\
\text { PC-3 vs. RWPE-1 cells }\end{array}$ & $\begin{array}{l}\text { sialyl-T antigen was extensively elevated in } \\
\text { all prostate cancer cell lines (VCaP, LNCaP, } \\
\text { DU145, PC-3) compared to normal RWPE- } 1 \\
\text { cells, especially in PC-3 cells }\end{array}$ & $\begin{array}{l}\text { Bai } 2020 \\
{[124]}\end{array}$ \\
\hline
\end{tabular}


Table 3. Cont.

\begin{tabular}{|c|c|c|c|c|}
\hline Type of Glycans & Structure & Sample Groups & Main Results & $\begin{array}{c}\text { Author, Year } \\
\text { References }\end{array}$ \\
\hline $\begin{array}{l}\text { core-2-O-linked } \\
\text { sLex }^{\mathrm{x}} \text { antigens }\end{array}$ & & $\begin{array}{l}\text { Malignant vs. } \\
\text { non-malignant } \\
\text { prostate tissues }\end{array}$ & $\begin{array}{l}\text { An increase in core-2-O-linked sLe }{ }^{\mathrm{x}} \\
\text { antigens on PSA, MUC-1, and PAP in } \\
\text { malignant relative to non-malignant } \\
\text { prostate tissues was observed }\end{array}$ & $\begin{array}{c}\text { Chen } 2014 \\
\text { [113] }\end{array}$ \\
\hline
\end{tabular}

Some studies have also examined the role of core-2-O-linked sLe ${ }^{\mathrm{x}}$ in prostate cancer, with a particular focus on metastatic disease $[113,125,126]$. Overexpression of $\mathrm{sLe}^{\mathrm{x}}$ has been correlated with an inferior prognosis, among patients with metastatic prostate cancer, and with castration-resistant, aggressive prostate cancer [113]. Highlighting the role of $\mathrm{O}$ glycans, Chen et al. found an increase in core-2-O-linked sLe $\mathrm{e}^{\mathrm{x}}$ antigens on PSA, MUC-1, and prostatic acid phosphatase (PAP) proteins in malignant relative to non-malignant prostate tissues, in patients who had undergone radical prostatectomy [113]. Many prostate cancer clinical trials have focused on mucin-1 (MUC-1), a single pass membrane protein, for which both the expression level of MUC-1 and its glycosylation were frequently altered [127]. An elevated MUC-1 level was detected in 58\% of primary tumor tissues and $90 \%$ of lymph node metastases, but not in healthy prostate or benign prostate tissues [128].

A recent study by Bai et al. showed that sialyl-T antigen was extensively elevated in all prostate cancer cell lines (VCaP, LNCaP, DU145, PC-3) compared to normal RWPE-1 cells, and it was particularly visible in PC-3 cells. Further research focused on examination of ST3Gal-I function in PC-3 cells; ST3Gal-I silencing studies indicated that ST3Gal-I is correlated with migration, proliferation and apoptosis of PC-3 cells. Subsequently, in vivo studies showed that decreased ST3Gal-I expression was associated with a reduction in tumor size in a xenograft mouse model, demonstrating that sialyl-T antigen could be considered as a biomarker for the prognosis of prostate cancer metastasis (Table 3) [124].

\section{Conclusions and Future Perspectives}

Glycoproteins are often considered as prognostic biomarkers for cancer diagnosis and monitoring of tumor progression, as well as predictive biomarkers for disease recurrence [129]. Researchers are constantly working on new approaches to the early diagnosis of prostate cancer, risk prediction and disease treatment, and emphasizing that glycans can be a source of new, non-invasive biomarkers. Glycoprotein markers are characterized by high heterogeneity, which results from multiple glycosylation sites and glycosylation patterns, and it has been emphasized that these features may significantly alter the selectivity of these molecules. Therefore, an attempt to broaden the knowledge of cancer-specific glycan structures and glycosylation sites, and then compare their patterns within a healthy population, can provide the first key step towards determining the importance of glycosylation in the diagnostic process. In view of these aspects, considerable efforts are still being made to standardize a glycomics protocol and implement modern, high-throughput mass spectrometry technology [77,130-132].

The biomarker most frequently used in prostate cancer diagnosis is prostate-specific antigen, but its limitations due to relatively low specificity restrict its use in screening tests and reduce the diagnostic potential $[59,133]$. The diminished sensitivity of these tests for early prostate cancer screening, along with the emergence of novel methods and technologies for glycan analysis, prompted the search for novel biomarkers based on the detection and identification of specific glycoforms of individual glycoproteins. This approach may lead to the establishment of new biomarkers with higher specificity for early cancer detection or for diagnosis in precancerous lesions [134,135]. Such research has become possible to carry out using newly developed, high-throughput platform technologies, 
which additionally enable the effective analysis of large sample cohorts [79,134]. Numerous studies have investigated whether a cancer-specific glycosylation pattern on PSA can be used to differentiate between BPH and PCa $[75,133]$. The most recent research on glycan composition in order to identify PCa and establish a prognosis has been conducted on diverse biological material, including serum [78], urine $[77,136]$, expressed prostatic secretion urine [137], formalin-fixed, paraffin-embedded (FFPE) tissues [138,139], cell lines [124,140], and exosomes [141].

Several studies have reported altered glycosylation, mainly both sialylation and fucosylation, in PSA as specific biomarkers of prostate cancer that are able to distinguish it from benign prostatic hyperplasia [73,133]. A crucial change in prostate cancer glycosylation is the increased level of sialylation, as well as the overexpression of cancer-related sialoglycans. Abnormal sialylation is evidently associated with tumor growth, invasion and enhanced cell survival and the onset of metastasis. Additionally, an increased level of the $\alpha 2,3$-sialylated isomer of PSA was noted as a distinctive feature of aggressive prostate cancer $[16,70,76]$; thus, analysis more targeted at aberrant sialylation is likely to be of significant therapeutic value [142]. Hence, a high-performance assay has recently been developed that allows for differentiation of $\alpha 2,3-$ and $\alpha 2,6$-linked sialic acid isomers of PSA in urine [136], and subsequently a mass spectrometric method for distinguishing $\alpha 2,3-$ and $\alpha 2,6$-sialoglycopeptide isomers in seminal plasma PSA was optimized [143], with good prospects for application of both methods in the diagnosis of prostate cancer. Thus, high-performance analysis of glycopeptides presenting prostate cancer-associated glycans has recently opened up new avenues for the discovery of glycoconjugates and glycoforms for the future emergence of cancer biomarkers with potential clinical applications [144].

In summary, composition of glycoproteins and glycans is likely to play an important role in both non-malignant prostate cancer and in prostate cancer. Hence in recent years, impressive progress in understanding their composition and function has been achieved. Numerous studies in this area have contributed to the emergence of glycans as promising biomarkers, highlighting their use in clinical settings as attractive targets for prostate cancer treatments $[48,59,145]$.

Author Contributions: Conceptualization, A.K. and M.F.-S.; data analysis, A.K.; writing—original draft preparation, A.K.; writing—review and editing, A.K. and M.F.-S.; visualization, A.K.; critical review of manuscript, A.K., J.S. and M.F.-S. All authors have read and agreed to the published version of the manuscript.

Funding: This research was funded by Wroclaw Medical University, Poland, No. SUB.A070.19.034.

Institutional Review Board Statement: Not applicable.

Informed Consent Statement: Not applicable.

Conflicts of Interest: The authors declare no conflict of interest.

\section{References}

1. Siegel, R.L.; Miller, K.D.; Jemal, A. Cancer statistics, 2020. CA Cancer J. Clin. 2020, 70, 7-30. [CrossRef] [PubMed]

2. Sung, H.; Ferlay, J.; Siegel, R.L.; Laversanne, M.; Soerjomataram, I.; Jemal, A.; Bray, F. Global Cancer Statistics 2020: GLOBOCAN Estimates of Incidence and Mortality Worldwide for 36 Cancers in 185 Countries. CA Cancer J Clin. 2021, 71, 209-249. [CrossRef]

3. Drake, R.R.; Jones, E.E.; Powers, T.W.; Nyalwidhe, J.O. Altered glycosylation in prostate cancer. Adv. Cancer Res. 2015, 126, 345-382. [CrossRef]

4. Kirwan, A.; Utratna, M.; O’Dwyer, M.E.; Joshi, L.; Kilcoyne, M. Glycosylation-Based Serum Biomarkers for Cancer Diagnostics and Prognostics. Biomed. Res. Int. 2015, 490531. [CrossRef]

5. Lilja, H.; Ulmert, D.; Vickers, A.J. Prostate-specific antigen and prostate cancer: Prediction, detection and monitoring. Nat. Rev. Cancer. 2008, 8, 268-278. [CrossRef]

6. Tkac, J.; Gajdosova, V.; Hroncekova, S.; Bertok, T.; Hires, M.; Jane, E.; Lorencova, L.; Kasak, P. Prostate-specific antigen glycoprofiling as diagnostic and prognostic biomarker of prostate cancer. Interface Focus. 2019, 9, 20180077. [CrossRef] [PubMed]

7. Carter, H.B.; Albertsen, P.C.; Barry, M.J.; Etzioni, R.; Freedland, S.J.; Greene, K.L.; Holmberg, L.; Kantoff, P.; Konety, B.R.; Murad, M.H.; et al. Early detection of prostate cancer: AUA Guideline. J. Urol. 2013, 190, 419-426. [CrossRef] 
8. Nordstrom, T.; Vickers, A.; Assel, M.; Lilja, H.; Gronberg, H.; Eklund, M. Comparison between the four-kallikrein panel and prostate health index for predicting prostate cancer. Eur. Urol. 2015, 68, 139-146. [CrossRef] [PubMed]

9. Sharma, P.; Zargar-Shoshtari, K.; Pow-Sang, J.M. Biomarkers for prostate cancer: Present challenges and future opportunities. Future Sci. OA 2016, 2, FSO72. [CrossRef] [PubMed]

10. Hatakeyama, S.; Yoneyama, T.; Tobisawa, Y.; Ohyama, C. Recent progress and perspectives on prostate cancer biomarkers. Int. J. Clin. Oncol. 2017, 22, 214-221. [CrossRef]

11. Chen, M.; Zhang, Q.; Zhang, C.; Zhao, X.; Marra, G.; Gao, J.; Lv, X.; Zhang, B.; Fu, Y.; Wang, F.; et al. Combination of 68Ga-PSMA PET/CT and Multiparametric MRI Improves the Detection of Clinically Significant Prostate Cancer: A Lesion-by-Lesion Analysis. J. Nucl. Med. 2019, 60, 944-949. [CrossRef]

12. Donswijk, M.L.; van Leeuwen, P.J.; Vegt, E.; Cheung, Z.; Heijmink, S.W.T.P.J.; van der Poel, H.G.; Stokkel, M.P.M. Clinical impact of PSMA PET/CT in primary prostate cancer compared to conventional nodal and distant staging: A retrospective single center study. BMC Cancer 2020, 20, 723. [CrossRef]

13. Merola, R.; Tomao, L.; Antenucci, A.; Sperduti, I.; Sentinelli, S.; Masi, S.; Mandoj, C.; Orlandi, G.; Papalia, R.; Guaglianone, S.; et al. PCA3 in prostate cancer and tumor aggressiveness detection on 407 high-risk patients: A National Cancer Institute experience. J. Exp. Clin. Cancer Res. 2015, 34, 15. [CrossRef]

14. Tajiri, M.; Ohyama, C.; Wada, Y. Oligosaccharide profiles of the prostate specific antigen in free and complexed forms from the prostate cancer patient serum and in seminal plasma: A glycopeptide approach. Glycobiology 2008, 18, 2-8. [CrossRef]

15. Sarrats, A.; Comet, J.; Tabarés, G.; Ramírez, M.; Aleixandre, R.N.; de Llorens, R.; Peracaula, R. Differential percentage of serum prostate-specific antigen subforms suggests a new way to improve prostate cancer diagnosis. Prostate 2010, 70, 1-9. [CrossRef] [PubMed]

16. Yoneyama, T.; Ohyama, C.; Hatakeyama, S.; Narita, S.; Habuchi, T.; Koie, T.; Mori, K.; Hidari, K.I.; Yamaguchi, M.; Suzuki, T.; et al. Measurement of aberrant glycosylation of prostate specific antigen can improve specificity in early detection of prostate cancer. Biochem. Biophys. Res. Commun. 2014, 448, 390-396. [CrossRef]

17. Franklin, R.B.; Milon, B.; Feng, P.; Costello, L.C. Zinc and zinc transporters in normal prostate and the pathogenesis of prostate cancer. Front. Biosci. 2005, 10, 2230-2239. [CrossRef]

18. Franz, M.C.; Anderle, P.; Bürzle, M.; Suzuki, Y.; Freeman, M.R.; Hediger, M.A.; Kovacs, G. Zinc transporters in prostate cancer. Mol. Asp. Med. 2013, 34, 735-741. [CrossRef] [PubMed]

19. Livermore, K.E.; Munkley, J.; Elliott, D.J. Androgen receptor and prostate cancer. AIMS Mol. Sci. 2016, 3, 280-299. [CrossRef]

20. Tan, M.H.; Li, J.; Xu, H.E.; Melcher, K.; Yong, E.L. Androgen receptor: Structure, role in prostate cancer and drug discovery. Acta Pharmacol. Sin. 2015, 36, 3-23. [CrossRef]

21. Davey, R.A.; Grossmann, M. Androgen Receptor Structure, Function and Biology: From Bench to Bedside. Clin. Biochem. Rev. 2016, 37, 3-15. [PubMed]

22. Feng, Q.; He, B. Receptor Signaling in the Development of Castration-Resistant Prostate Cancer. Front. Oncol. 2019, 9, 858. [CrossRef]

23. Dehm, S.M.; Tindall, D.J. Androgen receptor structural and functional elements: Role and regulation in prostate cancer. Mol. Endocrinol. 2007, 21, 2855-2863. [CrossRef] [PubMed]

24. Lamont, K.R.; Tindall, D.J. Androgen regulation of gene expression. Adv. Cancer Res. 2010, 107, 137-162. [CrossRef] [PubMed]

25. Takayama, K.; Inoue, S. Transcriptional network of androgen receptor in prostate cancer progression. Int. J. Urol. 2013, 20, 756-768. [CrossRef]

26. Costello, L.C.; Feng, P.; Milon, B.; Tan, M.; Franklin, R.B. Role of zinc in the pathogenesis and treatment of prostate cancer: Critical issues to resolve. Prostate Cancer Prostatic Dis. 2004, 7, 111-117. [CrossRef] [PubMed]

27. Costello, L.C.; Franklin, R.B.; Feng, P. Mitochondrial function, zinc, and intermediary metabolism relationships in normal prostate and prostate cancer. Mitochondrion 2005, 5, 143-153. [CrossRef]

28. Eidelman, E.; Twum-Ampofo, J.; Ansari, J.; Siddiqui, M.M. The Metabolic Phenotype of Prostate Cancer. Front. Oncol. 2017, 7, 131. [CrossRef]

29. Costello, L.C.; Franklin, R.B. The clinical relevance of the metabolism of prostate cancer; zinc and tumor suppression: Connecting the dots. Mol. Cancer 2006, 5, 17. [CrossRef]

30. Hanahan, D.; Weinberg, R.A. Hallmarks of cancer: The next generation. Cell 2011, 144, 646-674. [CrossRef]

31. Cutruzzolà, F.; Giardina, G.; Marani, M.; Macone, A.; Paiardini, A.; Rinaldo, S.; Paone, A. Glucose Metabolism in the Progression of Prostate Cancer. Front. Physiol. 2017, 8, 97. [CrossRef]

32. Mills, I.G. Maintaining and reprogramming genomic androgen receptor activity in prostate cancer. Nat. Rev. Cancer 2014, 14, 187-198. [CrossRef]

33. Munkley, J. Glycosylation is a global target for androgen control in prostate cancer cells. Endocr. Relat. Cancer 2017, 24, R49-R64. [CrossRef]

34. Ficarra, V.; Rossanese, M.; Zazzara, M.; Giannarini, G.; Abbinante, M.; Bartoletti, R.; Mirone, V.; Scaglione, F. The role of inflammation in lower urinary tract symptoms (LUTS) due to benign prostatic hyperplasia (BPH) and its potential impact on medical therapy. Curr. Urol. Rep. 2014, 15, 463-469. [CrossRef] [PubMed]

35. Wagenlehner, F.M.; Elkahwaji, J.E.; Algaba, F.; Bjerklund-Johansen, T.; Naber, K.G.; Hartung, R.; Weidner, W. The role of inflammation and infection in the pathogenesis of prostate carcinoma. BJU Int. 2007, 100, 733-737. [CrossRef] 
36. Gandaglia, G.; Briganti, A.; Gontero, P.; Mondaini, N.; Novara, G.; Salonia, A.; Sciarra, A.; Montorsi, F. The role of chronic prostatic inflammation in the pathogenesis and progression of benign prostatic hyperplasia (BPH). BJU Int. 2013, 112, $432-441$. [CrossRef]

37. Verze, P.; Cai, T.; Lorenzetti, S. The role of the prostate in male fertility, health and disease. Nat. Rev. Urol. 2016, 13, 379-386. [CrossRef]

38. Giri, D.; Ittmann, M. Interleukin-8 is a paracrine inducer of fibroblast growth factor 2, a stromal and epithelial growth factor in benign prostatic hyperplasia. Am. J. Pathol. 2001, 159, 139-147. [CrossRef]

39. Ludwig, J.A.; Weinstein, J.N. Biomarkers in cancer staging, prognosis and treatment selection. Nat. Rev. Cancer 2005, 5, 845-856. [CrossRef] [PubMed]

40. Badr, H.A.; Alsadek, D.M.; Darwish, A.A.; Elsayed, A.I.; Bekmanov, B.O.; Khussainova, E.M.; Zhang, X.; Cho, W.C.; Djansugurova, L.B.; Li, C.Z. Lectin approaches for glycoproteomics in FDA-approved cancer biomarkers. Expert Rev. Proteom. 2014, 11, 227-236. [CrossRef] [PubMed]

41. Dos Santos Silva, P.M.; Albuquerque, P.B.S.; de Oliveira, W.F.; Coelho, L.C.B.B.; Dos Santos Correia, M.T. Glycosylation products in prostate diseases. Clin. Chim. Acta 2019, 498, 52-61. [CrossRef] [PubMed]

42. Gabriele, C.; Prestagiacomo, L.E.; Cuda, G.; Gaspari, M. Mass Spectrometry-Based Glycoproteomics and Prostate Cancer. Int J. Mol. Sci. 2021, 22, 5222. [CrossRef] [PubMed]

43. White, K.Y.; Rodemich, L.; Nyalwidhe, J.O.; Comunale, M.A.; Clements, M.A.; Lance, R.S.; Schellhammer, P.F.; Mehta, A.S.; Semmes, O.J.; Drake, R.R. Glycomic characterization of prostate-specific antigen and prostatic acid phosphatase in prostate cancer and benign disease seminal plasma fluids. J. Proteome Res. 2009, 8, 620-630. [CrossRef]

44. Vermassen, T.; Speeckaert, M.M.; Lumen, N.; Rottey, S.; Delanghe, J.R. Glycosylation of prostate specific antigen and its potential diagnostic applications. Clin. Chim. Acta 2012, 413, 1500-1505. [CrossRef]

45. Pérez-Ibave, D.C.; Burciaga-Flores, C.H.; Elizondo-Riojas, M.Á. Prostate-specific antigen (PSA) as a possible biomarker in non-prostatic cancer: A review. Cancer Epidemiol. 2018, 54, 48-55. [CrossRef]

46. Schröder, F.H.; Hugosson, J.; Roobol, M.J.; Tammela, T.L.; Ciatto, S.; Nelen, V.; Kwiatkowski, M.; Lujan, M.; Lilja, H.; Zappa, M.; et al. Screening and prostate-cancer mortality in a randomized European study. N. Engl. J. Med. 2009, 360, 1320-1328. [CrossRef] [PubMed]

47. Stura, E.A.; Muller, B.H.; Bossus, M.; Michel, S.; Jolivet-Reynaud, C.; Ducancel, F. Crystal structure of human prostate-specific antigen in a sandwich antibody complex. J. Mol. Biol. 2011, 414, 530-544. [CrossRef]

48. Munkley, J.; Mills, I.G.; Elliott, D.J. The role of glycans in the development and progression of prostate cancer. Nat. Rev. Urol. 2016, 13, 324-333. [CrossRef] [PubMed]

49. Leymarie, N.; Griffin, P.J.; Jonscher, K.; Kolarich, D.; Orlando, R.; McComb, M.; Zaia, J.; Aguilan, J.; Alley, W.R.; Altmann, F.; et al. Interlaboratory study on differential analysis of protein glycosylation by mass spectrometry: The ABRF glycoprotein research multi-institutional study 2012. Mol. Cell Proteom. 2013, 12, 2935-2951. [CrossRef] [PubMed]

50. Kannagi, R.; Yin, J.; Miyazaki, K.; Izawa, M. Current relevance of incomplete synthesis and neo-synthesis for cancer-associated alteration of carbohydrate determinants-Hakomori's concepts revisited. Biochim. Biophys. Acta 2008, 1780, 525-531. [CrossRef]

51. Fujii, Y.; Yoshida, M.; Chien, L.J.; Kihara, K.; Kageyama, Y.; Yasukochi, Y.; Oshima, H. Significance of carbohydrate antigen sialylLewis $\mathrm{X}$, sialyl-Lewis A, and possible unknown ligands to adhesion of human urothelial cancer cells to activated endothelium. Urol. Int. 2000, 64, 129-133. [CrossRef]

52. Gill, D.J.; Chia, J.; Senewiratne, J.; Bard, F. Regulation of O-glycosylation through Golgi-to-ER relocation of initiation enzymes. J. Cell Biol. 2010, 189, 843-858. [CrossRef]

53. Pinho, S.S.; Oliveira, P.; Cabral, J.; Carvalho, S.; Huntsman, D.; Gärtner, F.; Seruca, R.; Reis, C.A.; Oliveira, C. Loss and recovery of Mgat3 and GnT-III mediated E-cadherin N-glycosylation is a mechanism involved in epithelial-mesenchymal-epithelial transitions. PLoS ONE 2012, 7, e33191. [CrossRef] [PubMed]

54. Liu, Y.C.; Yen, H.Y.; Chen, C.Y.; Chen, C.H.; Cheng, P.F.; Juan, Y.H.; Chen, C.H.; Khoo, K.H.; Yu, C.J.; Yang, P.C.; et al. Sialylation and fucosylation of epidermal growth factor receptor suppress its dimerization and activation in lung cancer cells. Proc. Natl. Acad. Sci. USA 2011, 108, 11332-11337. [CrossRef]

55. Scott, D.A.; Drake, R.R. Glycosylation and its implications in breast cancer. Expert Rev. Proteom. 2019, 16, 665-680. [CrossRef]

56. Mereiter, S.; Balmaña, M.; Campos, D.; Gomes, J.; Reis, C.A. Glycosylation in the Era of Cancer-Targeted Therapy: Where Are We Heading? Cancer Cell 2019, 36, 6-16. [CrossRef] [PubMed]

57. Deng, L.Q.; Chen, X.; Varki, A. Exploration of sialic acid diversity and biology using sialoglycan microarrays. Biopolymers 2013, 99, 650-665. [CrossRef] [PubMed]

58. Li, F.; Ding, J. Sialylation is involved in cell fate decision during development, reprogramming and cancer progression. Protein Cell 2019, 10, 550-565. [CrossRef] [PubMed]

59. Pinho, S.S.; Reis, C.A. Glycosylation in cancer: Mechanisms and clinical implications. Nat. Rev. Cancer 2015, 15, 540-555. [CrossRef] [PubMed]

60. Lu, J.; Gu, J. Significance of beta-galactoside alpha2,6 sialyltranferase 1 in cancers. Molecules 2015, 20, 7509-7527. [CrossRef]

61. Dimitroff, C.J. I-branched carbohydrates as emerging effectors of malignant progression. Proc. Natl. Acad. Sci. USA 2019, 116, 13729-13737. [CrossRef]

62. Garnham, R.; Scott, E.; Livermore, K.E.; Munkley, J. ST6GAL1: A key player in cancer. J. Oncol. Lett. 2019, 18, 983-989. [CrossRef] 
63. Zhuo, Y.; Bellis, S.L. Emerging role of alpha2,6-sialic acid as a negative regulator of galectin binding and function. J. Biol. Chem. 2011, 286, 5935-5941. [CrossRef] [PubMed]

64. Schultz, M.J.; Swindall, A.F.; Bellis, S.L. Regulation of the metastatic cell phenotype by sialylated glycans. Cancer Metastasis Rev. 2012, 31, 501-518. [CrossRef]

65. Falconer, R.A.; Errington, R.J.; Shnyder, S.D.; Smith, P.J.; Patterson, L.H. Polysialyltransferase: A new target in metastatic cancer. Curr. Cancer Drug Targets 2012, 12, 925-939. [CrossRef] [PubMed]

66. Blanas, A.; Sahasrabudhe, N.M.; Rodríguez, E.; van Kooyk, Y.; van Vliet, S.J. Fucosylated Antigens in Cancer: An Alliance toward Tumor Progression, Metastasis, and Resistance to Chemotherapy. Front. Oncol. 2018, 8, 39. [CrossRef]

67. Stowell, S.R.; Ju, T.; Cummings, R.D. Protein glycosylation in cancer. Annu. Rev. Pathol. 2015, 10, 473-510. [CrossRef] [PubMed]

68. Natoni, A.; Macauley, M.S.; O’Dwyer, M.E. Targeting selectins and their ligands in cancer. Front. Oncol. 2016, 6, 93. [CrossRef]

69. Borsig, L. Selectins in cancer immunity. Glycobiology 2018, 28, 648-655. [CrossRef]

70. Pihikova, D.; Kasak, P.; Kubanikova, P.; Sokol, R.; Tkac, J. Aberrant sialylation of a prostate-specific antigen: Electrochemical label free glycoprofiling in prostate cancer serum samples. Anal. Chim. Acta 2016, 934, 72-79. [CrossRef] [PubMed]

71. Peracaula, R.; Tabarés, G.; Royle, L.; Harvey, D.J.; Dwek, R.A.; Rudd, P.M.; de Llorens, R.R. Altered glycosylation pattern allows the distinction between prostate-specific antigen (PSA) from normal and tumor origins. Glycobiology 2003, 13, 457-470. [CrossRef] [PubMed]

72. Ohyama, C.; Hosono, M.; Nitta, K.; Oh-eda, M.; Yoshikawa, K.; Habuchi, T.; Arai, Y.; Fukuda, M. Carbohydrate structure and differential binding of prostate specific antigen to Maackia amurensis lectin between prostate cancer and benign prostate hypertrophy. Glycobiology 2004, 14, 671-679. [CrossRef]

73. Saldova, R.; Fan, Y.; Fitzpatrick, J.M.; Watson, R.W.; Rudd, P.M. Core fucosylation and alpha2-3 sialylation in serum N-glycome is significantly increased in prostate cancer comparing to benign prostate hyperplasia. Glycobiology 2011, 21, 195-205. [CrossRef] [PubMed]

74. Ferrer-Batallé, M.; Llop, E.; Ramírez, M.; Aleixandre, R.N.; Saez, M.; Comet, J.; de Llorens, R.; Peracaula, R. Comparative study of blood-based biomarkers, alpha2,3-sialic acid PSA and PHI, for high-risk prostate cancer detection. Int. J. Mol. Sci. 2017, 18, 845. [CrossRef] [PubMed]

75. Llop, E.; Ferrer-Batallé, M.; Barrabés, S.; Guerrero, P.E.; Ramírez, M.; Saldova, R.; Rudd, P.M.; Aleixandre, R.N.; Comet, J.; de Llorens, R.; et al. Improvement of prostate cancer diagnosis by detecting PSA glycosylation-specific changes. Theranostics 2016, 6 , 1190-1204. [CrossRef]

76. Ishikawa, T.; Yoneyama, T.; Tobisawa, Y.; Hatakeyama, S.; Kurosawa, T.; Nakamura, K.; Narita, S.; Mitsuzuka, K.; Duivenvoorden, W.; Pinthus, J.H.; et al. An automated micro-total immunoassay system for measuring cancer-associated alpha2,3-linked sialyl $\mathrm{N}$-glycan-carrying prostate-specific antigen may improve the accuracy of prostate cancer diagnosis. Int. J. Mol. Sci. 2017, 18, 470. [CrossRef]

77. Yang, S.; Clark, D.; Liu, Y.; Li, S.; Zhang, H. High-throughput analysis of N-glycans using AutoTip via glycoprotein immobilization. Sci. Rep. 2017, 7, 10216. [CrossRef]

78. Gilgunn, S.; Murphy, K.; Stöckmann, H.; Conroy, P.J.; Murphy, T.B.; Watson, R.W.; O’Kennedy, R.J.; Rudd, P.M.; Saldova, R. Glycosylation in Indolent, Significant and Aggressive Prostate Cancer by Automated High-Throughput N-Glycan Profiling. Int. J. Mol. Sci. 2020, 21, 9233. [CrossRef] [PubMed]

79. Gratacós-Mulleras, A.; Duran, A.; Asadi Shehni, A.; Ferrer-Batallé, M.; Ramírez, M.; Comet, J.; de Llorens, R.; Saldova, R.; Llop, E.; Peracaula, R. Characterisation of the main PSA glycoforms in aggressive prostate cancer. Sci. Rep. 2020, 10, 18974. [CrossRef]

80. Wang, X.; Chen, J.; Li, Q.K.; Peskoe, S.B.; Zhang, B.; Choi, C.; Platz, E.A.; Zhang, H. Overexpression of alpha $(1,6)$ fucosyltransferase associated with aggressive prostate cancer. Glycobiology 2014, 24, 935-944. [CrossRef]

81. Potapenko, I.O.; Haakensen, V.D.; Lüders, T.; Helland, A.; Bukholm, I.; Sørlie, T.; Kristensen, V.N.; Lingjaerde, O.C.; Børresen-Dale, A.L. Glycan gene expression signatures in normal and malignant breast tissue; possible role in diagnosis and progression. Mol. Oncol. 2010, 4, 98-118. [CrossRef] [PubMed]

82. Li, J.; Guillebon, A.D.; Hsu, J.W.; Barthel, S.R.; Dimitroff, C.J.; Lee, Y.F.; King, M.R. Human fucosyltransferase 6 enables prostate cancer metastasis to bone. Br. J. Cancer 2013, 109, 3014-3022. [CrossRef] [PubMed]

83. Barthel, S.R.; Wiese, G.K.; Cho, J.; Opperman, M.J.; Hays, D.L.; Siddiqui, J.; Pienta, K.J.; Furie, B.; Dimitroff, C.J.; Barthel, S.R.; et al. Alpha 1,3 fucosyltransferases are master regulators of prostate cancer cell trafficking. Proc. Natl. Acad. Sci. USA 2009, 106, 19491-19496. [CrossRef] [PubMed]

84. Scott, E.; Munkley, J. Glycans as Biomarkers in Prostate Cancer. Int. J. Mol. Sci. 2019, 20, 1389. [CrossRef]

85. Shah, P.; Wang, X.; Yang, W.; Toghi Eshghi, S.; Sun, S.; Hoti, N.; Chen, L.; Yang, S.; Pasay, J.; Rubin, A.; et al. Integrated proteomic and glycoproteomic analyses of prostate cancer cells reveal glycoprotein alteration in protein abundance and glycosylation. Mol. Cell. Proteom. 2015, 14, 2753-2763. [CrossRef]

86. Höti, N.; Yang, S.; Hu, Y.; Shah, P.; Haffner, M.C.; Zhang, H. Overexpression of alpha $(1,6)$ fucosyltransferase in the development of castration-resistant prostate cancer cells. Prostate Cancer Prostatic Dis. 2018, 21, 137-146. [CrossRef]

87. Tu, C.F.; Wu, M.Y.; Lin, Y.C.; Kannagi, R.; Yang, R.B. FUT8 promotes breast cancer cell invasiveness by remodeling TGF- $\beta$ receptor core fucosylation. Breast Cancer Res. 2017, 19, 111. [CrossRef] [PubMed]

88. Dahmani, A.; Delisle, J.S. TGF- $\beta$ in T Cell Biology: Implications for Cancer Immunotherapy. Cancers 2018, 10, 194. [CrossRef] [PubMed] 
89. Buffone, A.; Weaver, V.M. Don't sugarcoat it: How glycocalyx composition influences cancer progression. J. Cell Biol. 2020, 219, e201910070. [CrossRef]

90. Chen, C.Y.; Jan, Y.H.; Juan, Y.H.; Yang, C.J.; Huang, M.S.; Yu, C.J.; Yang, P.C.; Hsiao, M.; Hsu, T.L.; Wong, C.H. Fucosyltransferase 8 as a functional regulator of nonsmall cell lung cancer. Proc. Natl. Acad. Sci. USA 2013, 110, 630-635. [CrossRef]

91. Bastian, K.; Scott, E.; Elliott, D.J.; Munkley, J. FUT8 Alpha-(1,6)-Fucosyltransferase in Cancer. Int. J. Mol. Sci. 2021, 22, 455. [CrossRef]

92. Kyselova, Z.; Mechref, Y.; Al Bataineh, M.M.; Dobrolecki, L.E.; Hickey, R.J.; Vinson, J.; Sweeney, C.J.; Novotny, M.V. Alterations in the serum glycome due to metastatic prostate cancer. J. Proteome Res. 2007, 6, 1822-1832. [CrossRef]

93. Fujita, K.; Shimomura, M.; Uemura, M.; Nakata, W.; Sato, M.; Nagahara, A.; Nakai, Y.; Takamatsu, S.; Miyoshi, E.; Nonomura, N. Serum fucosylated haptoglobin as a novel prognostic biomarker predicting high-gleason prostate cancer. Prostate 2014, 74, 1052-1058. [CrossRef]

94. Wang, C.; Höti, N.; Lih, T.M.; Sokoll, L.J.; Zhang, R.; Zhang, Z.; Zhang, H.; Chan, D.W. Development of a glycoproteomic strategy to detect more aggressive prostate cancer using lectin-immunoassays for serum fucosylated PSA. Clin. Proteom. 2019, 16, 13. [CrossRef]

95. Nyalwidhe, J.O.; Betesh, L.R.; Powers, T.W.; Jones, E.E.; White, K.Y.; Burch, T.C.; Brooks, J.; Watson, M.T.; Lance, R.S.; Troyer, D.A.; et al. Increased bisecting $\mathrm{N}$-acetylglucosamine and decreased branched chain glycans of N-linked glycoproteins in expressed prostatic secretions associated with prostate cancer progression. Proteom. Clin. Appl. 2013, 7, 677-689. [CrossRef]

96. Ishibashi, Y.; Tobisawa, Y.; Hatakeyama, S.; Ohashi, T.; Tanaka, M.; Narita, S.; Koie, T.; Habuchi, T.; Nishimura, S.; Ohyama, C.; et al. Serum tri- and tetra-antennary $\mathrm{N}$-glycan is a potential predictive biomarker for castration-resistant prostate cancer. Prostate 2014, 74, 1521-1529. [CrossRef]

97. Lange, T.; Ullrich, S.; Müller, I.; Nentwich, M.F.; Stübke, K.; Feldhaus, S.; Knies, C.; Hellwinkel, O.J.; Vessella, R.L.; Abramjuk, C.; et al. Human prostate cancer in a clinically relevant xenograft mouse model: Identification of beta(1,6)-branched oligosaccharides as a marker of tumor progression. Clin. Cancer Res. 2012, 18, 1364-1373. [CrossRef]

98. Haga, Y.; Uemura, M.; Baba, S.; Inamura, K.; Takeuchi, K.; Nonomura, N.; Ueda, K. Identification of Multisialylated LacdiNAc Structures as Highly Prostate Cancer Specific Glycan Signatures on PSA. Anal. Chem. 2019, 91, 2247-2254. [CrossRef] [PubMed]

99. Fukushima, K.; Satoh, T.; Baba, S.; Yamashita, K. alpha1,2-Fucosylated and beta-N-acetylgalactosaminylated prostate-specific antigen as an efficient marker of prostatic cancer. Glycobiology 2010, 20, 452-460. [CrossRef]

100. Kaya, T.; Kaneko, T.; Kojima, S.; Nakamura, Y.; Ide, Y.; Ishida, K.; Suda, Y.; Yamashita, K. High-sensitivity immunoassay with surface plasmon field-enhanced fluorescence spectroscopy using a plastic sensor chip: Application to quantitative analysis of total prostate-specific antigen and GalNAcbeta1-4GlcNAc-linked prostate-specific antigen for prostate cancer diagnosis. Anal. Chem. 2015, 87, 1797-1803. [CrossRef]

101. Clark, D.J.; Schnaubelt, M.; Hoti, N.; Hu, Y.; Zhou, Y.; Gooya, M.; Zhang, H. Impact of Increased FUT8 Expression on the Extracellular Vesicle Proteome in Prostate Cancer Cells. J. Proteome Res. 2020, 19, 2195-2205. [CrossRef] [PubMed]

102. Hakomori, S. Glycosylation defining cancer malignancy: New wine in an old bottle. Proc. Natl. Acad. Sci. USA 2002, 99, 10231-10233. [CrossRef] [PubMed]

103. Darby, J.F.; Gilio, A.K.; Piniello, B.; Roth, C.; Blagova, E.; Hubbard, R.E.; Rovira, C.; Davies, G.J.; Wu, L. Substrate engagement and catalytic mechanisms of N-acetylglucosaminyltransferase V. ACS Catal. 2020, 10, 8590-8596. [CrossRef]

104. Rabinovich, G.A.; Toscano, M.A. Turning 'sweet' on immunity: Galectin-glycan interactions in immune tolerance and inflammation. Nat. Rev. Immunol. 2009, 9, 338-352. [CrossRef] [PubMed]

105. Croci, D.O.; Cerliani, J.P.; Dalotto-Moreno, T.; Méndez-Huergo, S.P.; Mascanfroni, I.D.; Dergan-Dylon, S.; Toscano, M.A.; Caramelo, J.J.; García-Vallejo, J.J.; Ouyang, J.; et al. Glycosylation-dependent lectin-receptor interactions preserve angiogenesis in anti-VEGF refractory tumors. Cell 2014, 156, 744-758. [CrossRef]

106. Tsui, K.H.; Chang, P.L.; Feng, T.H.; Chung, L.C.; Sung, H.C.; Juang, H.H. Evaluating the function of matriptase and Nacetylglucosaminyltransferase V in prostate cancer metastasis. Anticancer Res. 2008, 28, 1993-1999.

107. Murphy, K.; Murphy, B.T.; Boyce, S.; Flynn, L.; Gilgunn, S.; O’Rourke, C.J.; Rooney, C.; Stöckmann, H.; Walsh, A.L.; Finn, S.; et al. Integrating biomarkers across omic platforms: An approach to improve stratification of patients with indolent and aggressive prostate cancer. Mol. Oncol. 2018, 12, 1513-1525. [CrossRef]

108. Machado, E.; Kandzia, S.; Carilho, R.; Altevogt, P.; Conradt, H.S.; Costa, J. N-Glycosylation of total cellular glycoproteins from the human ovarian carcinoma SKOV3 cell line and of recombinantly expressed human erythropoietin. Glycobiology 2011, 21, 376-386. [CrossRef]

109. Hirano, K.; Matsuda, A.; Shirai, T.; Furukawa, K. Expression of LacdiNAc groups on N-glycans among human tumors is complex. Biomed. Res. Int. 2014, 2014, 981627. [CrossRef]

110. Hagiwara, K.; Tobisawa, Y.; Kaya, T.; Kaneko, T.; Hatakeyama, S.; Mori, K.; Hashimoto, Y.; Koie, T.; Suda, Y.; Ohyama, C.; et al. Wisteria floribunda agglutinin and its reactive-glycan-carrying prostate-specific antigen as a novel diagnostic and prognostic marker of prostate cancer. Int. J. Mol. Sci. 2017, 18, 261. [CrossRef]

111. Yoneyama, T.; Tobisawa, Y.; Kaneko, T.; Kaya, T.; Hatakeyama, S.; Mori, K.; Sutoh Yoneyama, M.; Okubo, T.; Mitsuzuka, K.; Duivenvoorden, W.; et al. Clinical significance of the LacdiNAc-glycosylated prostate-specific antigen assay for prostate cancer detection. Cancer Sci. 2019, 110, 2573-2589. [CrossRef] [PubMed] 
112. Radhakrishnan, P.; Dabelsteen, S.; Madsen, F.B.; Francavilla, C.; Kopp, K.L.; Steentoft, C.; Vakhrushev, S.Y.; Olsen, J.V.; Hansen, L.; Bennett, E.P.; et al. Immature truncated O-glycophenotype of cancer directly induces oncogenic features. Proc. Natl. Acad. Sci. USA 2014, 111, E4066-E4075. [CrossRef]

113. Chen, Z.; Gulzar, Z.G.; St Hill, C.A.; Walcheck, B.; Brooks, J.D. Increased expression of GCNT1 is associated with altered O-glycosylation of PSA, PAP, and MUC1 in human prostate cancers. Prostate 2014, 74, 1059-1067. [CrossRef]

114. Kojima, Y.; Yoneyama, T.; Hatakeyama, S.; Mikami, J.; Sato, T.; Mori, K.; Hashimoto, Y.; Koie, T.; Ohyama, C.; Fukuda, M.; et al. Detection of core2 beta-1,6-N-acetylglucosaminyltransferase in post-digital rectal examination urine is a reliable indicator for extracapsular extension of prostate cancer. PLoS ONE 2015, 10, e0138520. [CrossRef]

115. Sato, T.; Yoneyama, T.; Tobisawa, Y.; Hatakeyama, S.; Yamamoto, H.; Kojima, Y.; Mikami, J.; Mori, K.; Hashimoto, Y.; Koie, T.; et al. Core 2 beta-1,6-N-acetylglucosaminyltransferase- 1 expression in prostate biopsy specimen is an indicator of prostate cancer aggressiveness. Biochem. Biophys. Res. Commun. 2016, 470, 150-156. [CrossRef]

116. Kudelka, M.R.; Ju, T.; Heimburg-Molinaro, J.; Cummings, R.D. Simple sugars to complex disease-mucin-type O-glycans in cancer. Adv. Cancer Res. 2015, 126, 53-135. [CrossRef]

117. Dimitroff, C.J. Galectin-binding O-glycosylations as regulators of malignancy. Cancer Res. 2015, 75, 3195-3202. [CrossRef]

118. Munkley, J.; Oltean, S.; Vodák, D.; Wilson, B.T.; Livermore, K.E.; Zhou, Y.; Star, E.; Floros, V.I.; Johannessen, B.; Knight, B.; et al. The androgen receptor controls expression of the cancer-associated sTn antigen and cell adhesion through induction of ST6GalNAc1 in prostate cancer. Oncotarget 2015, 6, 34358-34374. [CrossRef] [PubMed]

119. Munkley, J.; Vodak, D.; Livermore, K.E.; James, K.; Wilson, B.T.; Knight, B.; Mccullagh, P.; Mcgrath, J.; Crundwell, M.; Harries, L.W.; et al. Glycosylation is an androgen-regulated process essential for prostate cancer cell viability. EBioMedicine 2016, 8, 103-116. [CrossRef]

120. Munkley, J. The Role of Sialyl-Tn in Cancer. Int. J. Mol. Sci. 2016, 17, 275. [CrossRef]

121. Dobie, C.; Skropeta, D. Insights into the role of sialylation in cancer progression and metastasis. Br. J. Cancer 2021, 124, 76-90. [CrossRef]

122. Wong, N.; Major, P.; Kapoor, A.; Wei, F.; Yan, J.; Aziz, T.; Zheng, M.; Jayasekera, D.; Cutz, J.C.; Chow, M.J.; et al. Amplification of MUC1 in prostate cancer metastasis and CRPC development. Oncotarget 2016, 7, 83115-83133. [CrossRef] [PubMed]

123. Arai, T.; Fujita, K.; Fujime, M.; Irimura, T. Expression of sialylated MUC1 in prostate cancer: Relationship to clinical stage and prognosis. Int. J. Urol. 2005, 12, 654-661. [CrossRef] [PubMed]

124. Bai, R.; Luan, X.; Zhang, Y.; Robbe-Masselot, C.; Brockhausen, I.; Gao, Y. The expression and functional analysis of the sialyl-T antigen in prostate cancer. Glycoconj. J. 2020, 37, 423-433. [CrossRef] [PubMed]

125. Hagisawa, S.; Ohyama, C.; Takahashi, T.; Endoh, M.; Moriya, T.; Nakayama, J.; Arai, Y.; Fukuda, M. Expression of core 2 beta1,6-N-acetylglucosaminyltransferase facilitates prostate cancer progression. Glycobiology 2005, 15, 1016-1024. [CrossRef]

126. Okamoto, T.; Yoneyama, M.S.; Hatakeyama, S.; Mori, K.; Yamamoto, H.; Koie, T.; Saitoh, H.; Yamaya, K.; Funyu, T.; Fukuda, M.; et al. Core2 O-glycan-expressing prostate cancer cells are resistant to NK cell immunity. Mol. Med. Rep. 2013, 7, 359-364. [CrossRef]

127. Nath, S.; Mukherjee, P. MUC1: A multifaceted oncoprotein with a key role in cancer progression. Trends Mol. Med. 2014, 20, 332-342. [CrossRef]

128. Cozzi, P.J.; Wang, J.; Delprado, W.; Perkins, A.C.; Allen, B.J.; Russell, P.J.; Li, Y. MUC1, MUC2, MUC4, MUC5AC and MUC6 expression in the progression of prostate cancer. Clin. Exp. Metastasis 2005, 22, 565-573. [CrossRef]

129. Reis, C.A.; Osorio, H.; Silva, L.; Gomes, C.; David, L. Alterations in glycosylation as biomarkers for cancer detection. J. Clin. Pathol. 2010, 63, 322-329. [CrossRef]

130. York, W.S.; Agravat, S.; Aoki-Kinoshita, K.F.; McBride, R.; Campbell, M.P.; Costello, C.E.; Dell, A.; Feizi, T.; Haslam, S.M.; Karlsson, N.; et al. MIRAGE: The minimum information required for a glycomics experiment. Glycobiology 2014, 24, 402-406. [CrossRef]

131. Struwe, W.B.; Agravat, S.; Aoki-Kinoshita, K.F.; Campbell, M.P.; Costello, C.E.; Dell, A.; Feizi, T.; Haslam, S.M.; Karlsson, N.G.; Khoo, K.H.; et al. The minimum information required for a glycomics experiment (MIRAGE) project: Sample preparation guidelines for reliable reporting of glycomics datasets. Glycobiology 2016, 26, 907-910. [CrossRef]

132. Peixoto, A.; Relvas-Santos, M.; Azevedo, R.; Santos, L.L.; Ferreira, J.A. Protein glycosylation and tumor microenvironment alterations driving cancer hallmarks. Front. Oncol. 2019, 9, 380. [CrossRef]

133. Gilgunn, S.; Conroy, P.J.; Saldova, R.; Rudd, P.M.; O’Kennedy, R.J. Aberrant PSA glycosylation-a sweet predictor of prostate cancer. Nat. Rev. Urol. 2013, 10, 99-107. [CrossRef] [PubMed]

134. Adamczyk, B.; Tharmalingam, T.; Rudd, P.M. Glycans as cancer biomarkers. Biochim. Biophys. Acta 2012, 1820, 1347-1353. [CrossRef]

135. Reider, B.; Jarvas, G.; Krenkova, J.; Guttman, A. Separation based characterization methods for the N-glycosylation analysis of prostate-specific antigen. J. Pharm. Biomed. Anal. 2021, 194, 113797. [CrossRef]

136. Kammeijer, G.S.M.; Nouta, J.; de la Rosette, J.J.M.C.H.; de Reijke, T.M.; Wuhrer, M. An In-Depth Glycosylation Assay for Urinary Prostate-Specific Antigen. Anal. Chem. 2018, 90, 4414-4421. [CrossRef] [PubMed]

137. Jia, G.; Dong, Z.; Sun, C.; Wen, F.; Wang, H.; Guo, H.; Gao, X.; Xu, C.; Xu, C.; Yang, C.; et al. Alterations in expressed prostate secretion-urine PSA N-glycosylation discriminate prostate cancer from benign prostate hyperplasia. Oncotarget 2017, 8 , 76987-76999. [CrossRef] 
138. Powers, T.W.; Neely, B.A.; Shao, Y.; Tang, H.; Troyer, D.A.; Mehta, A.S.; Haab, B.B.; Drake, R.R. MALDI imaging mass spectrometry profiling of N-glycans in formalin-fixed paraffin embedded clinical tissue blocks and tissue microarrays. PLoS ONE 2014, 9, e106255. [CrossRef]

139. Mantsiou, A.; Makridakis, M.; Fasoulakis, K.; Katafigiotis, I.; Constantinides, C.A.; Zoidakis, J.; Roubelakis, M.G.; Vlahou, A.; Lygirou, V. Proteomics Analysis of Formalin Fixed Paraffin Embedded Tissues in the Investigation of Prostate Cancer. J. Proteome Res. 2020, 19, 2631-2642. [CrossRef] [PubMed]

140. Ideo, H.; Kondo, J.; Nomura, T.; Nonomura, N.; Inoue, M.; Amano, J. Study of glycosylation of prostate-specific antigen secreted by cancer tissue-originated spheroids reveals new candidates for prostate cancer detection. Sci. Rep. 2020, 10, 2708. [CrossRef] [PubMed]

141. Øverbye, A.; Skotland, T.; Koehler, C.J.; Thiede, B.; Seierstad, T.; Berge, V.; Sandvig, K.; Llorente, A. Identification of prostate cancer biomarkers in urinary exosomes. Oncotarget 2015, 6, 30357-30376. [CrossRef]

142. Munkley, J.; Scott, E. Targeting Aberrant Sialylation to Treat Cancer. Medicines 2019, 6, 102. [CrossRef] [PubMed]

143. Wang, W.; Kałuża, A.; Nouta, J.; Nicolardi, S.; Ferens-Sieczkowska, M.; Wuhrer, M.; Lageveen-Kammeijer, G.S.M.; de Haan, N. High-throughput glycopeptide profiling of prostate-specific antigen from seminal plasma by MALDI-MS. Talanta 2021, 222, 121495. [CrossRef] [PubMed]

144. Illiano, A.; Pinto, G.; Melchiorre, C.; Carpentieri, A.; Faraco, V.; Amoresano, A. Protein Glycosylation Investigated by Mass Spectrometry: An Overview. Cells 2020, 9, 1986. [CrossRef] [PubMed]

145. Costa, A.F.; Campos, D.; Reis, C.A.; Gomes, C. Targeting Glycosylation: A New Road for Cancer Drug Discovery. Trends Cancer 2020, 6, 757-766. [CrossRef] 